\title{
Brine sludge waste from a Chlor-alkali industry: characterization and its application for non-structural and structural construction materials
}

\author{
Juliana de C. Izidoro ${ }^{1, *}\left(\mathbb{D}\right.$, Denise A. Fungaro ${ }^{1}$ (i) Luciana C. Viviani ${ }^{2}$ and, Rogério da Costa Silva ${ }^{2}$ \\ ${ }^{1}$ Instituto de Pesquisas Energéticas e Nucleares, IPEN-CNEN/SP, 05508-000, Brazil \\ ${ }^{2}$ Unipar Carbocloro S.A., 04543-011, Brazil
}

\begin{abstract}
Brine sludge (BS) is an industrial waste generated in large amounts by the Chlor-alkali industry and, usually disposed into industrial landfills. Because BS contains several chemical compounds, also presents a potential environmental impact. The feasibility of the utilization of brine sludge wastes for the preparation of value-added materials was investigated. The characterization of two brine sludge samples was performed in terms of chemical and physical composition, particle size distribution, X-ray diffraction (XRD), Fourier Transform Infrared Spectroscopy (FTIR), and thermal analysis (DTA/TG). Elements like $\mathrm{Ca}, \mathrm{Si}, \mathrm{Na}, \mathrm{Mg}, \mathrm{Al}, \mathrm{Cl}$, and Fe were identified in the samples. The XRD results confirmed the crystalline nature of compounds and indicated that the main compounds in brine sludge samples were calcium carbonate, sodium chloride, magnesium hydroxide, and quartz. FTIR showed the presence of varying functional groups like carbonate, siloxane, and hydroxide. The two brine sludge samples can be considered as a fine powder with the mean diameter $\left(\mathrm{d}_{50}\right)$ of $4.984 \mu \mathrm{m}$ and $24.574 \mu \mathrm{m}$, for the BS from Santo André and Cubatão, respectively. The results indicated that the brine sludge samples presented favorable characteristics to use limestone filler and binder alternative to Portland cement in the nonstructural construction materials. The incorporation of brine sludge in geopolymeric materials is another possible use in sustainable construction material products. The production of value-added products from brine sludge will be an important contribution towards sustainable development adopted by the Chlor-alkali industry.
\end{abstract}

Key words: Chlor-alkali industry; Industrial solid waste; Brine Sludge; Eco-friendly concrete; Geopolymer composite.

\section{INTRODUCTION}

The Chlor-alkali industry is essential to the chemical industry because it is responsible for the production of chlorine, which has many applications such as chemicals, pharmaceuticals, ultra-pure metals, polymers, and others $[1,2]$, besides the caustic soda production, which can be applied in the manufacture of almost all chemical products.

Regardless of the type of technology adopted for chlorine and caustic soda production (membrane cells, asbestos diaphragm, or mercury cell), salt is used as raw material and needs treatment before electrolysis.

During the salt treatment, the Chlor-alkali industry generates large amounts of brine sludge (BS). That industrial waste is generated in large amounts in Brazil and usually disposed into industrial landfills.

Although brine sludge generated from the different Chlor-alkali industries from different countries presents potential recycling and reuse [3-6], there are no many studies that address the characterization of this type of waste generated in Brazil.

Therefore, the present work aims to characterize, evaluate, and correlate the physical and chemical characteristics of two brine sludge samples from the Unipar Carbocloro S. A. chemical industry (Brazil) to propose possibilities of application.

\section{EXPERIMENTAL SECTION}

\subsection{Materials}

The brine sludge wastes were collected at Unipar Carbocloro S.A. units located in Cubatão (São Paulo/ Brazil) and Santo André (São Paulo/Brazil). The samples were first dried at $105 \pm 5^{\circ} \mathrm{C}$ for 24 hours. After cooling to room temperature, the brine sludge samples were grounded.

\subsection{Characterization of brine sludge samples}

The brine sludge samples collected at Cubatão City (BSCB) and Santo André City (BSSA) were characterized by different techniques. The chemical compositions in the form of oxides were analyzed by energy dispersive XRFX-ray fluorescence spectrometry using Malvern Analytical, Zetim model. X-ray diffraction (XRD) analyzes were performed on an X'Pert, Philips diffractometer, operating with $\mathrm{Cu}$ Karadiation $(\lambda=1,542 \AA)$, scanning from 5 to $50^{\circ}$ at a rate of $1 \%$ min with a voltage of $40 \mathrm{kV}$ and current of $50 \mathrm{~mA}$. Particle size distribution of samples was determined by DPSA using Malvern Instruments, Mastersizer 2000, Ver. 5.54 , with the sample dispersed in isopropyl alcohol and analyzed by $\mathrm{He}-\mathrm{Ne}$ laser. Functional groups within the material structure were identified by FTIR (Perkin Elmer

$\begin{array}{ll}\text { Received } & \text { : June 15, 2021 } \\ \text { Revised } & \text { : July 16, 2021 } \\ \text { Accepted } & \text { : August 28, 2021 }\end{array}$


Frontier) using $\mathrm{KBr}$ as a medium. IR spectra were scanned in the range of $4,000 \mathrm{~cm}^{-1}$ to $400 \mathrm{~cm}^{-1}$ with a resolution of 4 $\mathrm{cm}^{-1}$. Thermogravimetric analysis was conducted using a Q500 thermogravimetric analyzer (TA Instruments). Thus, samples were heated from 50 to $1000{ }^{\circ} \mathrm{C}$ at a rate of $10{ }^{\circ} \mathrm{C} /$ min under air at a flow rate of $60 \mathrm{~mL} / \mathrm{min}$. Samples had an average mass of $9 \mathrm{mg}$. The $\mathrm{pH}$ was measured as follows: 0.25 $\mathrm{g}$ of each sample was placed in $25 \mathrm{~mL}$ of deionized water and the mixture was stirred during $24 \mathrm{~h}$ in a shaker at $120 \mathrm{rpm}$ (Ética - Mod 430). After filtration, the $\mathrm{pH}$ of the solutions was measured with a $\mathrm{pH}$ meter (MSTecnopon - Mod MPA 210). The bulk density was determined from the weight of the sample divided by the volume of $35 \mathrm{~mL}$ of the sample in a beaker. All BS samples characterization was performed at the Laboratório de Caracterização Tecnológica - Escola Politécnica da Universidade de São Paulo (LCT-POLI/ USP).

\section{RESULTS AND DISCUSSION}

\subsection{Mineralogical composition}

Identification of the phases present in the brine sludge samples was carried out by comparing the experimental interplanar spacing ( $d$ values) with those of the respective likely substances listed in the PDF2 of ICDD (International Centre for Diffraction Data) and ICSD (Inorganic Crystal Structure Database). The X-ray diffraction spectra (XRD) of BS samples from Santo André and Cubatão are shown in Fig. 1 and 2, respectively. There is a great similarity between the diffractograms of the samples, despite being of different origins. The XRD patterns are composed of sharp multiple peaks indicating that the samples have a predominance of crystalline structure.

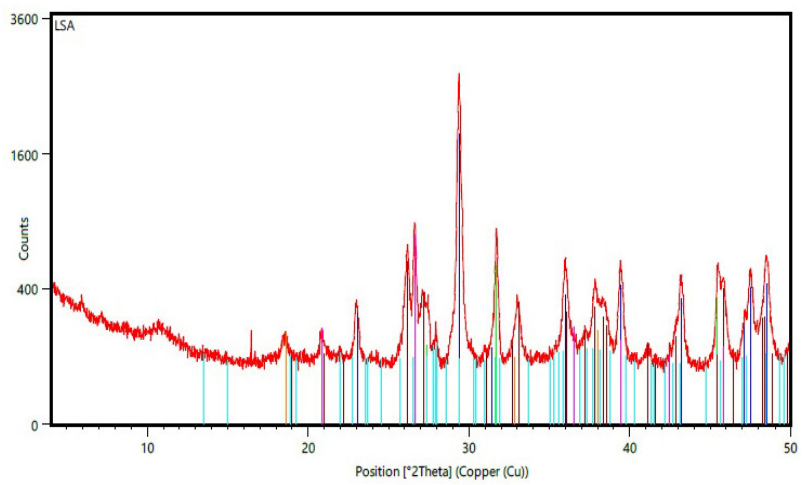

Fig. 1. XRD pattern of brine sludge from Santo André (BSSA).

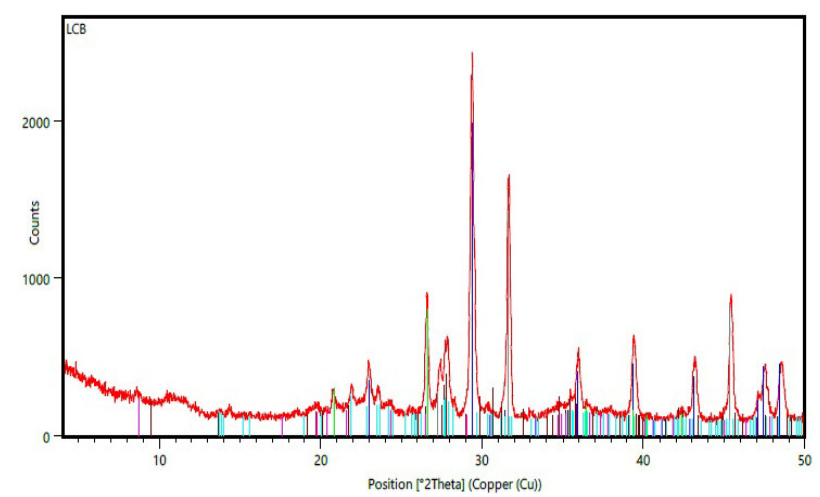

Fig. 2. XRD pattern of brine sludge from Cubatão (BSCB).
The observed $d$ values confirm the presence of multi-elemental, diverse mineralogical phases as shown in Table 1 and Table 2 for BSSA and BSCB, respectively.

Table 1 Crystalline phases, formulas, and diffraction patterns identified in the BSSA sample.

\begin{tabular}{lcc}
\hline Compound & Formula & Diffraction pattern \\
\hline Calcite & $\mathrm{CaCO}_{3}$ & $01-0862334$ \\
Aragonite & $\mathrm{CaCO}_{3}$ & $01-071-2396$ \\
Halite & $\mathrm{NaCl}$ & $01-075-0306$ \\
Quartz & $\mathrm{SiO}_{2}$ & $01-079-1906$ \\
Brucite $^{*}$ & $\mathrm{Mg}(\mathrm{OH})_{2}$ & $01-074-2226$ \\
Anortite $^{*}$ & $\mathrm{CaAl}_{2} \mathrm{Si}_{2} \mathrm{O}_{8}$ & $00-041-1486$ \\
Amorphous phase $^{*}$ & - & - \\
\hline
\end{tabular}

*Possible presence

Table 2 Crystalline phases, formulas, and diffraction patterns identified in the BSCB sample.

\begin{tabular}{lcc}
\hline Compound & Formula & $\begin{array}{c}\text { Diffraction } \\
\text { pattern }\end{array}$ \\
\hline Calcite & $\mathrm{CaCO}_{3}$ & $01-0862334$ \\
Halite & $\mathrm{NaCl}$ & $01-075-0306$ \\
Quartz & $\mathrm{SiO}_{2}$ & $01-089-8935$ \\
Enstatite & $\left(\mathrm{Fe}_{0,084} \mathrm{Mg}_{0,916}\right)$ & $01-083-0667$ \\
& $\left(\mathrm{Fe}_{0,414} \mathrm{Mg}_{0,586}\right)$ & \\
& $\mathrm{Si}_{2} \mathrm{O}_{6}$ & \\
Albite & $\left.\mathrm{Na} \mathrm{AlSi}_{3} \mathrm{O}_{8}\right)$ & $01-083-1607$ \\
Muscovite & $\mathrm{KAl}_{2} \mathrm{Si}_{3} \mathrm{AlO}_{10}$ & \\
& $(\mathrm{OH})_{2}$ & \\
Amorphous phase* & - & - \\
\hline
\end{tabular}

*Possible presence

\subsection{Chemical composition and physical-chemical properties}

The chemical composition of the brine sludge wastes is given in Table 3. The majority composition is calcium. The other most abundant elements are $\mathrm{Si}, \mathrm{Mg}, \mathrm{Na}, \mathrm{Cl}$, and $\mathrm{Fe}$. These elements are the main constituents of minerals present in the wastes, such as calcite, halite, quartz, and brucite (Fig. 1 and Fig. 2). In addition, the BSCB also presents a relatively large presence of $\mathrm{Al}$.

The high loss on ignition presented in the chemical composition of $41 \%$ and $36 \%$ for BSSA and BSCB, respectively can be associated with volatile constituents and the presence of carbonate materials in the residues.

The results of physical and chemical analysis of sludge samples are given in Table 4 . The bulk density of a powder is dependent on its particle size distribution. A coarse homogenous powder has a lower bulk density than a fine homogenous powder, therefore, the value of the sample BSCB is less than that of the sample BSSA. The $\mathrm{pH}$ value indicates that samples were moderately alkaline in nature due to the presence of oxides, which hydrolyze in the presence of water. 
Table 3 Chemical composition (wt\%) of brine sludges samples.

\begin{tabular}{|c|c|c|}
\hline Element & BSSA & BSCB \\
\hline $\mathrm{Ca}$ & 39.8 & 20.3 \\
\hline $\mathrm{Mg}$ & 6.50 & 7.56 \\
\hline $\mathrm{Na}$ & 2.91 & 6.10 \\
\hline $\mathrm{Si}$ & 2.13 & 10.1 \\
\hline $\mathrm{Cl}$ & 5.13 & 9.56 \\
\hline $\mathrm{Fe}$ & 4.20 & 5.02 \\
\hline $\mathrm{Al}$ & 0.65 & 3.63 \\
\hline $\mathrm{P}$ & 0.03 & 0.07 \\
\hline$S$ & 0.40 & 0.10 \\
\hline $\mathrm{K}$ & 0.21 & 1.19 \\
\hline $\mathrm{Ti}$ & 0.10 & 0.31 \\
\hline $\mathrm{Cr}$ & - & 0.09 \\
\hline $\mathrm{Mn}$ & 0.05 & 0.10 \\
\hline $\mathrm{Ni}$ & - & 0.02 \\
\hline $\mathrm{Cu}$ & - & 0.02 \\
\hline $\mathrm{Zn}$ & 0.05 & 0.08 \\
\hline As & - & 0.02 \\
\hline $\mathrm{Br}$ & 0.02 & - \\
\hline $\mathrm{Rb}$ & - & 0.01 \\
\hline $\mathrm{Sr}$ & 2.69 & 0.16 \\
\hline $\mathrm{Zr}$ & - & 0.09 \\
\hline $\mathrm{Ba}$ & - & 0.03 \\
\hline $\mathrm{Pb}$ & - & 0.02 \\
\hline LOI* & 40.6 & 36.1 \\
\hline
\end{tabular}

$\left({ }^{*}\right)$ Loss on Ignition

Table 4 Chemical and physical properties of the sludge samples.

\begin{tabular}{ccc}
\hline Properties & BSSA & BSCB \\
\hline Color & light Grey & reddish \\
Bulk density $(\mathrm{g} / \mathrm{mL})$ & 0.728 & 0.648 \\
$\mathrm{pH}$ & 8.77 & 7.97 \\
\hline
\end{tabular}

\subsection{Particle size distribution}

The differential and cumulative particle size distributions are shown in Fig. 3 and Fig. 4 for BSSA and $\mathrm{BSCB}$, respectively. The differential size distribution of BSSA is relatively uniform with a bell-shaped asymmetric distribution curve while that of the BSCB sample tends to show a bimodal particle size distribution.

The particle size distributions of materials are given in Table 4. These distributions specify that the majority of particles (90\%) lie below $\sim 18 \mu \mathrm{m}$ for BSSA and $\sim 130 \mu \mathrm{m}$ for BSCB. Therefore, most of the particles have a size that corresponds to the silt fraction in BSSA and the sand fraction in BSCB. A previous study showed that the particle size distributions of a brine sludge sample presented a range from $0.075 \mathrm{~mm}$ to $4.75 \mathrm{~mm}$ for up $60 \%$ of particles [6].

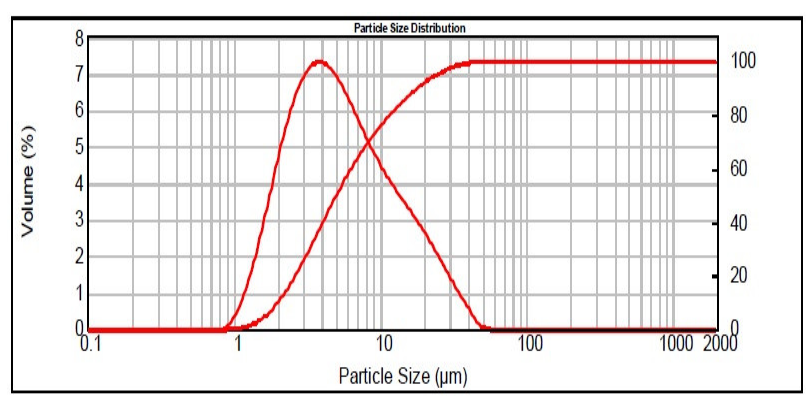

Fig. 3. Particle size distribution of BSSA.

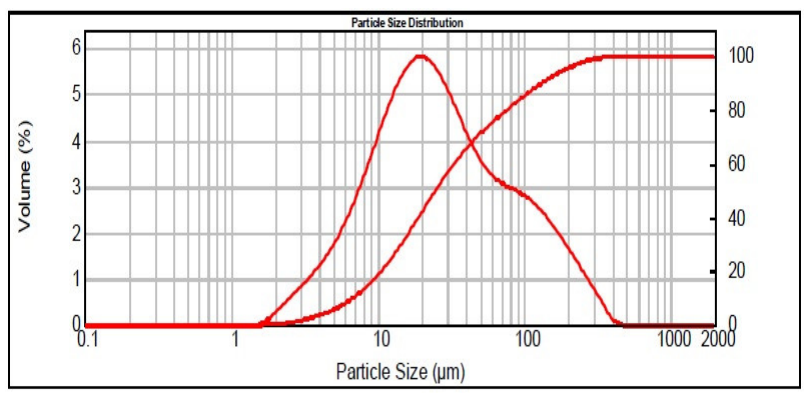

Fig. 4. Particle size distribution of BSCB.

Table 5 Particle size distributions of brine sludge samples.

\begin{tabular}{cccccc}
\hline \multirow{2}{*}{ Samples } & \multicolumn{5}{c}{ Particle diameter $(\mu \mathrm{m})$} \\
\cline { 2 - 6 } & $\mathrm{D}_{3.2}$ & $\mathrm{D}_{4.3}$ & $\mathrm{D}_{10}$ & $\mathrm{D}_{50}$ & $\mathrm{D}_{90}$ \\
\hline BSSA & 4.056 & 7.724 & 1.984 & 4.984 & 17.672 \\
BSCB & 15.466 & 49.192 & 6.724 & 24.574 & 129.71 \\
\hline
\end{tabular}

\subsection{FTIR studies}

The relevant vibration bands of the brine sludge samples in FTIR spectra were determined in the range of $400-4000 \mathrm{~cm}^{-1}$ and are shown in Fig. 5 (a) and (b) for BSSA and $\mathrm{BSCB}$, respectively. Table 6 summarizes the wavenumbers at which the absorption maxima appear in the spectra of the materials and their vibrational assignments.

Calcium carbonate is a major component of brine sludge samples and the FTIR spectrum is very useful for distinguishing among different phases of this compound. The crystal phases of calcium carbonate can be discriminated by detecting the absorption bands.

The vibration frequencies observed were characteristic of two crystalline calcium carbonate phases (calcite and aragonite). Typically, the absorption bands were divided into four parts: the symmetric stretch of the carbonate ion at about $1080 \mathrm{~cm}^{-1}(v 1)$; the out-of-plane bending absorption at about $870 \mathrm{~cm}^{-1}(v 2)$; the asymmetric stretch at about 1400 $\mathrm{cm}^{-1}(v 3)$ and the in-plane bending at about $700 \mathrm{~cm}^{-1}(v 4)$ [7]. Each phase of calcium carbonate has some characteristic absorption bands. The bands at $\sim 1480 \mathrm{~cm}^{-1}, 1083 \mathrm{~cm}^{-1}, 858$ $\mathrm{cm}^{-1}$ are characteristics of aragonite $[7,8]$.

The presence of $\mathrm{H}_{2} \mathrm{O}$ is detected by two characteristic absorption bands in the $3670-3440 \mathrm{~cm}^{-1}$ region corresponding to the stretching and deformation modes of $\mathrm{OH}^{-}$and in the $1640 \mathrm{~cm}^{-1}$ region associated with bending vibration mode of $\mathrm{H}_{2} \mathrm{O}$ [9]. 

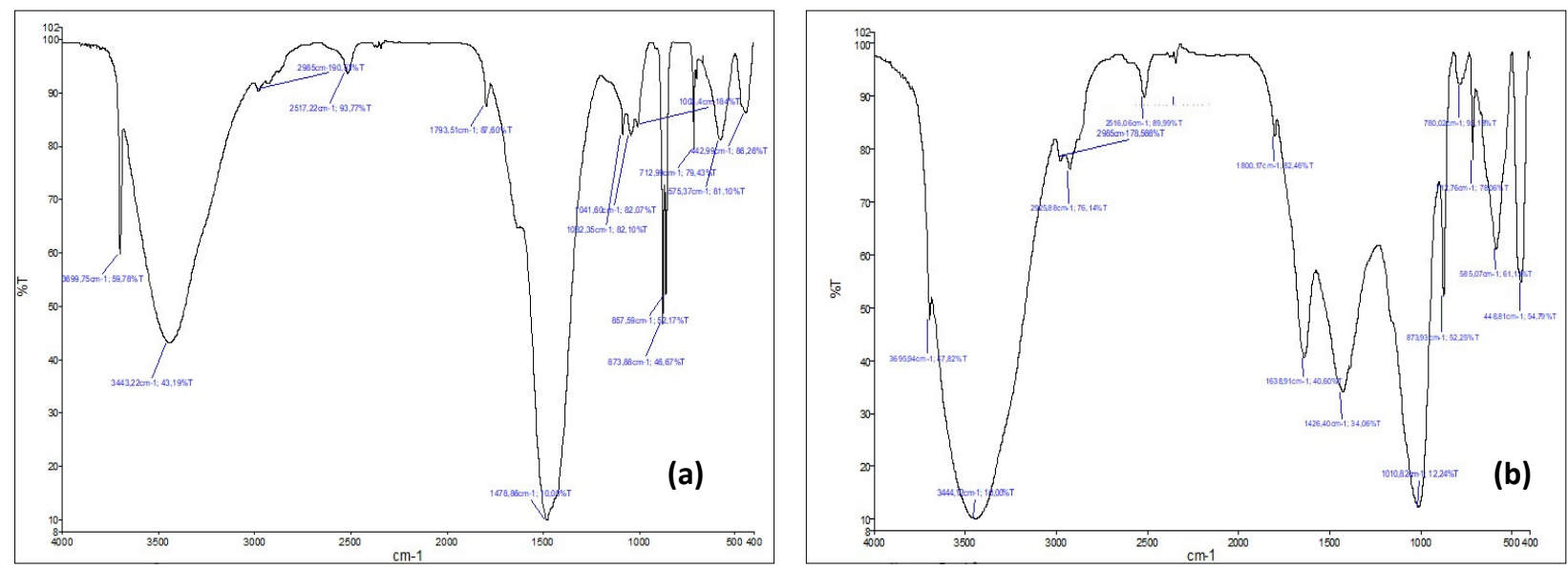

Fig. 5. FTIR spectrum of (a) BSSA and (b) BSCB.

Table 6 IR bands of brine sludge samples along with their assignments.

\begin{tabular}{|c|c|c|}
\hline \multicolumn{2}{|c|}{ Wavenumber $\left(\mathrm{cm}^{-1}\right)$} & \multirow{2}{*}{ Assignments } \\
\hline BSCB & BSSA & \\
\hline 3695.94 & 3699.75 & $\begin{array}{l}\text { stretching and deformation of adsorbed water molecule } \\
\text { asymmetric stretching vibrations of } \mathrm{OH}^{-} \text {groups from } \mathrm{Mg}(\mathrm{OH})_{2}\end{array}$ \\
\hline 3444.12 & 3443.22 & stretching and deformation of adsorbed water molecule \\
\hline 2925.88 & - & saturated $\mathrm{C}-\mathrm{H}$ vibration from some impurity in the $\mathrm{KBr}$ Crystal \\
\hline 2516.06 & 2517.22 & atmospheric $\mathrm{CO}_{2}$ \\
\hline 2344.05 & - & atmospheric $\mathrm{CO}_{2}$ \\
\hline 1800.17 & 1793.51 & symmetric vibration $(v 1+v 4) \mathrm{CO}_{3}$ \\
\hline 1638.91 & - & $\mathrm{Si}-\mathrm{O}-\mathrm{Si}$ asymmetric stretching and bending vibrations of water molecules \\
\hline 1426.4 & 1478.86 & symmetric vibration $v 3\left(\mathrm{CO}_{3}\right)$ \\
\hline- & 1082.35 & symmetric vibration $v 1\left(\mathrm{CO}_{3}\right)$ \\
\hline 1010.82 & 1041.6 & symmetric stretching of $\mathrm{Si}-\mathrm{O}-\mathrm{Si}$ \\
\hline 873.93 & 873.88 & asymmetric vibration $v 2\left(\mathrm{CO}_{3}\right)$ \\
\hline- & 857.59 & out-of-plane bending vibration $v 4\left(\mathrm{CO}_{3}\right)$ \\
\hline 780.02 & - & symmetric stretching of $\mathrm{Si}-\mathrm{O}-\mathrm{Si}$ \\
\hline 712.76 & 712.99 & symmetric vibration $v 4\left(\mathrm{CO}_{3}\right)$ \\
\hline 585,07 & 575.37 & Si-O-Al bond \\
\hline 448.81 & 442.99 & symmetric stretching of $\mathrm{Si}-\mathrm{O}-\mathrm{Si}$ and asymmetric bending of $\mathrm{Si}-\mathrm{O}$ \\
\hline
\end{tabular}

A broad absorption band at $\sim 3670 \mathrm{~cm}^{-1}$ indicate also the presence of the characteristic frequency of the hydroxyl group $\left(\mathrm{OH}^{-}\right)$stretching vibration of magnesium hydroxide $[10,11]$.

The minor peak at $2900 \mathrm{~cm}^{-1}$ is associated with a saturated $\mathrm{C}-\mathrm{H}$ vibration from some impurity in the $\mathrm{KBr}$ crystals and those minor peaks observed at 2500-2300 $\mathrm{cm}^{-1}$ were due to the adsorption of the atmospheric $\mathrm{CO}_{2}$ [12-14].

The presence of quartz was identified by the characteristic absorption bands at 448, 780, 1010-1040, and $1640 \mathrm{~cm}^{-1}$. Among these bands, the absorption at $\sim 800 \mathrm{~cm}^{-1}$, which is due to $\mathrm{Si}-\mathrm{O}-\mathrm{Si}$ symmetrical stretching vibration is the most suitable band for silica determination $[15,16]$. The absorption bands at $585-575 \mathrm{~cm}^{-1}$ indicate the formation of the Si-O-Al bond [17].

\subsection{Thermal analysis}

The thermogravimetric analysis is important to check the thermal stability of the material and it is useful for the strategic design of sludge management when thermal treatment is involved. Fig. 6 and 7 show TGA and derivative TGA (DTG) curves of BSSA and BSCB samples, respectively. The peak of the DTG curve represents the temperature corresponding to the highest mass loss rate for the samples. Analyzing the thermogravimetric curves, it is possible to observe a thermal behavior similar between the two samples. The first peaks observed at $\sim 306-338{ }^{\circ} \mathrm{C}$ corresponds to the decomposition of magnesium compounds [18]. For sample BSCB (Fig. 8), the DTG curve in this temperature range shows two peaks, which are related to two reactions that are partially overlapping. Around $650-860{ }^{\circ} \mathrm{C}$ is observed the signal due to the $\mathrm{CO}_{2}$ loss corresponding to the decarbonization of the calcite [19]. 
BSSA sample presented higher content of $\mathrm{CaCO}_{3}$ in agreement with the data reported by the chemical analysis. The peak near $430^{\circ} \mathrm{C}$ for the BSCB sample may be attributed to the quartz dehydroxylation due to the condensation of silanol groups resulting in the loss of water [20]. High residual mass was found for both samples at the end of the analysis ( $60 \%)$ probably due to high inorganic contents, mainly salts.

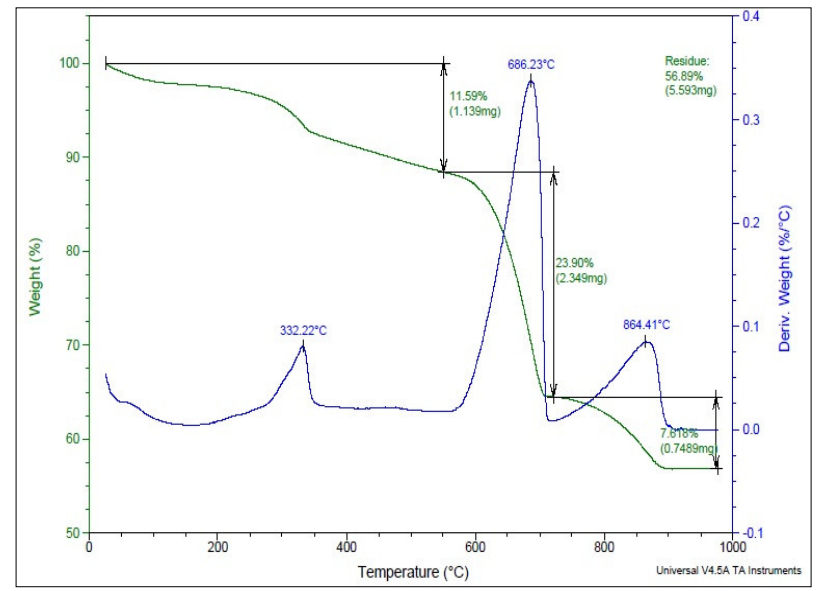

Fig. 6. TG and DTG curves of BSSA.

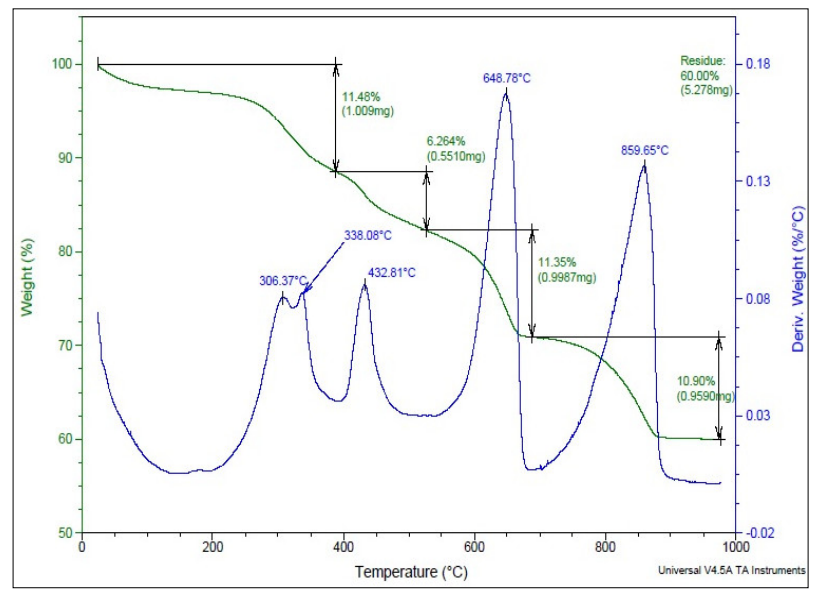

Fig. 7. TG and DTG curves of BSCB.

\subsection{Evaluation of brine sludge waste applications}

Many advantages recycling the wastes can bring, such as avoiding pollution caused by incorrect disposal, reducing the number of raw materials used to produce products, and reducing costs. Therefore, applications for brine sludges will be discussed.

\subsubsection{Utilization of Brine Sludge samples in Nonstructural Building Components}

Portland cement is the most used binder in the manufacture of concrete. Greenhouse gas emissions owing to Portland cement production correspond to $5-8 \%$ of anthropogenic emissions. To limit the impact of climate change, it is mandatory to reduce carbon emissions and to lower the $\mathrm{CO}_{2}$ concentration in the atmosphere. The use of supplementary cementitious materials in concrete reduces $\mathrm{CO}_{2}$ emissions and saves non-renewable resources [21-23].

The results indicated that brine sludge (both samples) has the potential to be used as a limestone filler alternative due to its fine granulometry and its composition. The limestone filler is a product of the crushing of the limestone rock, which can be calcitic or dolomitic. It is an extremely fine powder, which is widely used as a filling material in cement, concrete, and mortar, increasing compactness through the best particle size distribution [24].

The two samples can be used in partial replacement of Portland cement and the nonstructural construction materials, such as paver blocks, mortars, and bricks [25].

The effect of binders with different particle size distributions on cement-based materials was reported by Mehdipour and Khayat [26]. In addition, the sludge samples have also the potential to be used as a chemically reactive binder. The $\mathrm{Ca}^{2+}$ ions can react with silica and alumina present in cement forming calcium silicates and aluminates which bind the entire mass together producing a solidified matrix $[4,23]$. Further, magnesium oxide content present in brine sludges can cause a decrease in the shrinkage strain of cementitious materials improving their structural and durability [27].

Another advantage in preparing construction materials with the incorporation of these residues is that the toxic metal ions present in them will be immobilized in the prepared composite.

\subsubsection{Utilization of Brine Sludge samples in Geopolymerized Based Composites}

A geopolymeric composite can be developed by incorporating industrial waste. The utilization of industrial waste to develop geopolymer concrete has a significant positive impact on the environment based on sustainability indicators [28-31].

The incorporation of brine sludge samples containing calcium carbonate, magnesium hydroxide, sodium chloride, and silica can cause improvements in the interfacial bonding of the geopolymeric matrix due to the additional formation of C-S-H gel or A-S-H gel together with N-S-H or N-A-S-H/ C-A-S-H gel $[3,5]$. The simultaneous presence of this variety of gels modifies the physical and mechanical properties of geopolymer materials. There should be improvements in resistance to compression and flexion due to the formation of dense microstructure [32-34].

The high calcium content can contribute to the greater compaction of geopolymer structures. Chloride, on the other hand, works as a catalyst improving the geopolymerization reaction and leading to the formation of geopolymeric gel $[3,5]$. In addition, geopolymer materials also have the potential to immobilize toxic ions present in wastes.

\section{CONCLUSION}

The two brine sludge samples presented $\mathrm{Ca}, \mathrm{Si}, \mathrm{Na}, \mathrm{Mg}$, $\mathrm{Al}, \mathrm{Cl}$, and $\mathrm{Fe}$ in their chemical compositions. The majority composition was calcium for both samples. In addition, the $\mathrm{BSCB}$ also presents a relatively large presence of $\mathrm{Al}$. The high loss on ignition presented in the chemical composition of $41 \%$ and $36 \%$ for BSSA and BSCB, respectively can be associated with volatile constituents and the presence of carbonate materials in the residues. 
The XRD results confirmed the crystalline nature of compounds and indicated that the main compounds in brine sludge samples were calcium carbonate, sodium chloride, magnesium hydroxide, and quartz. The $\mathrm{pH}$ value indicates that samples were moderately alkaline in nature due to the presence of oxides, which hydrolyze in the presence of water.

The differential size distribution of BSSA is relatively uniform with a bell-shaped asymmetric distribution curve while that of the BSCB sample tends to show a bimodal particle size distribution. The particle size distributions of materials specify that the majority of particles (90\%) lie below $\sim 18 \mu \mathrm{m}$ for BSSA and $\sim 130 \mu \mathrm{m}$ for BSCB. Therefore, most of the particles have a size that corresponds to the silt fraction in BSSA and the sand fraction in BSCB. The two brine sludge samples can be considered as a fine powder with the mean diameter $\left(\mathrm{d}_{50}\right)$ of $4.984 \mu \mathrm{m}$ and $24.574 \mu \mathrm{m}$, for the BS from Santo André and Cubatão, respectively.

FTIR showed the presence of varying functional groups like carbonate, siloxane, and hydroxide for both samples. BSSA and BSCB also presented a very similar thermal behavior, with the decomposition of magnesium compounds and $\mathrm{CO}_{2}$ loss due to decarbonization of calcite.

The results indicate that the brine sludge samples present favorable characteristics for to be used as limestone filler and binder alternative to Portland cement in the nonstructural construction materials. The incorporation of brine sludge in geopolymeric materials is another possible use in sustainable construction material products. The production of value-added products from brine sludge will be an important contribution towards sustainable development adopted by the Chlor-alkali industry.

\section{AUTHOR INFORMATION}

\section{Corresponding Author}

*Email: Julianaizidoro@usp.br

\section{ORCID}

Juliana Izidoro : : :0000-0002-3466-5196

Denise Alves Fungaro : 0000-0003-1618-0264

\section{REFERENCES}

[1] Fauvarque Jacqueline. The Chlorine Industry. Pure and Applied Chemistry. 1996; 68(9)

[2] Modern Chlor-Alkali Technology. Springer: Netherlands.

[3] Verma Sarika, Amritphale S. S., Khan Mohd. Akram, Anshul Avneesh, Das Satyabrata. Development of Advanced Geopolymerized Brine Sludge Based Composites. Journal of Polymers and the Environment. 2016; 25(4)

[4] Garg Mridul, Pundir Aakanksha. Utilization of Brine Sludge in Nonstructural Building Components: A Sustainable Approach. Journal of Waste Management. 2014; 2014

[5] Verma Sarika, Amritphale S. S., Khan Mohd. Akram. Utilization of Brine Sludge and Fly Ash Waste as Complementary Resources, for Making Non-toxic, Geopolymeric (Cement-Free) Materials. Iranian Journal of Science and Technology, Transactions of Civil Engineering. 2018; 43(S1)
[6] Chen Shin Jen, Chen Chao Shi, Jhan Jyun Yong, Chen Ruei Fu. Utilization of Brine Sludge in Controlled Low Strength Materials (CLSM). Key Engineering Materials. 2019; 801

[7] Andersen F. A., Brecevic L.. ChemInform Abstract: Infrared Spectra of Amorphous and Crystalline Calcium Carbonate.. ChemInform. 2010; 23(9)

[8] Rodriguez-Blanco Juan Diego, Shaw Samuel, Benning Liane G.. The kinetics and mechanisms of amorphous calcium carbonate (ACC) crystallization to calcite, viavaterite.. Nanoscale. 2011; 3(1)

[9] Stomp Maayke, Huisman Jef, Stal Lucas J, Matthijs Hans C P. Colorful niches of phototrophic microorganisms shaped by vibrations of the water molecule. The ISME Journal. 2007; 1(4)

[10] Gao Rui, Wang Jun, Zhang Xiaofei, Yan Huijun, Yang Wanlu, Liu Qi, Zhang Milin, Liu Lianhe, Takahashi Kazunobu. Fabrication of superhydrophobic magnesium alloy through the oxidation of hydrogen peroxide. Colloids and Surfaces A: Physicochemical and Engineering Aspects. 2013; 436

[11] Pilarska Agnieszka, Wysokowski Marcin, Markiewicz Ewa, Jesionowski Teofil. Synthesis of magnesium hydroxide and its calcinates by a precipitation method with the use of magnesium sulfate and poly (ethylene glycols). Powder Technology. 2013; 235

[12] Ding Yi, Zhang Guangtao, Zhang Shuyuan, Huang Xinming, Yu Weichao, Qian Yitai. Preparation and Characterization of Magnesium Hydroxide Sulfate Hydrate Whiskers. Chemistry of Materials. 2000; 12(10)

[13] Rodriguez-Navarro Carlos, Suzuki Amelia, RuizAgudo Encarnacion. Alcohol Dispersions of Calcium Hydroxide Nanoparticles for Stone Conservation. Langmuir. 2013; 29(36)

[14] Samanta Aniruddha, Chanda Dipak K., Das Pradip Sekhar, Ghosh Jiten, Mukhopadhyay Anoop Kumar, Dey Arjun. Synthesis of Nano Calcium Hydroxide in Aqueous Medium. Journal of the American Ceramic Society. 2015; 99(3)

[15] Ojima Jun. Determining of Crystalline Silica in Respirable Dust Samples by Infrared Spectrophotometry in the Presence of Interferences. Journal of Occupational Health. 2003; 45(2)

[16] Rovani Suzimara, Santos Jonnatan J., Corio Paola, Fungaro Denise A.. Highly Pure Silica Nanoparticles with High Adsorption Capacity Obtained from Sugarcane Waste Ash. ACS Omega. 2018; 3(3)

[17] Chen Tingjie, Niu Min, Xie Yongqun, Wu Zhenzeng, Liu Xiaozheng, Cai Lili, Zhuang Biaorong. Modification of Ultra-Low Density Fiberboards by an Inorganic Film Formed by Si-Al Deposition and their Mechanical Properties. BioResources. 2015; 10(1)

[18] Wang J.A, Novaro O, Bokhimi X, López T, Gómez R, Navarrete J, Llanos M.E, López-Salinas E. Characterizations of the thermal decomposition of brucite prepared by sol-gel technique for synthesis of nanocrystalline $\mathrm{MgO}$. Materials Letters. 1998; 35 (5-6) 
[19] Singh N. B., Singh N. P.. Formation of $\mathrm{CaO}$ from thermal decomposition of calcium carbonate in the presence of carboxylic acids. Journal of Thermal Analysis and Calorimetry. 2007; 89(1)

[20] Hong Hun Gi, Sackett Debra D., Mallouk Thomas E.. Adsorption of well-ordered zirconium phosphonate multilayer films on high surface area silica. Chemistry of Materials. 1991; 3(3)

[21] Duchesne J.. Alternative supplementary cementitious materials for sustainable concrete structures: a review on characterization and properties. Waste and Biomass Valorization. 2020; 12(3)

[22] Nicoara Adrian Ionut, Stoica Alexandra Elena, Vrabec Mirijam, Šmuc Rogan Nastja, Sturm Saso, Ow-Yang Cleva, Gulgun Mehmet Ali, Bundur Zeynep Basaran, Ciuca Ion, Vasile Bogdan Stefan. End-of-Life Materials Used as Supplementary Cementitious Materials in the Concrete Industry. Materials. 2020; 13(8)

[23] Scrivener Karen L., John Vanderley M., Gartner Ellis M.. Eco-efficient cements: Potential economically viable solutions for a low-CO2 cement-based materials industry. Cement and Concrete Research. 2018; 114

[24] Aqel Mohmmad, Panesar Daman. Physical and chemical effects of limestone filler on the hydration of steam cured cement paste and mortar. Revista ALCONPAT. 2020; 10(2)

[25] Singh Suryansh, Khan Maaz Allah, Yadav Vipin Kumar, Yadav Akash Singh, Sharan Upendra. Utilization of Brine Sludge in Manufacturing of Fly Ash Bricks. International Journal of Engineering Development and Research. 2020; 8(1)

[26] Mehdipour Iman, Khayat Kamal H.. Effect of particle -size distribution and specific surface area of different binder systems on packing density and flow characteristics of cement paste. Cement and Concrete Composites. 2017; 78

[27] Gonçalves T., Silva R. V., de Brito J., Fernández J. M., Esquinas A. R. Hydration of Reactive $\mathrm{MgO}$ as Partial Cement Replacement and Its Influence on the Macroperformance of Cementitious Mortars. Advances in Materials Science and Engineering. 2019; 2019

[28] Azad Numanuddin M., Samarakoon S.M. Samindi M.K.. Utilization of Industrial By-Products/ Waste to Manufacture Geopolymer Cement/ Concrete. Sustainability. 2021; 13(2)

[29] Luhar Ismail, Luhar Salmabanu, Abdullah Mohd Mustafa Al Bakri, Nabiałek Marcin, Sandu Andrei Victor, Szmidla Janusz, Jurczyńska Anna, Razak Rafiza Abdul, Aziz Ikmal Hakem A, Jamil Noorina Hidayu, Deraman Laila Mardiah. Assessment of the Suitability of Ceramic Waste in Geopolymer Composites: An Appraisal. Materials. 2021; 14(12)

[30] Mohajerani Abbas, Suter David, Jeffrey-Bailey Tristan, Song Tianyang, Arulrajah Arul, Horpibulsuk Suksun, Law David. Recycling waste materials in geopolymer concrete. Clean Technologies and Environmental Policy. 2019; 21(3)
[31] Luhar Salmabanu, Cheng Ta-Wui, Nicolaides Demetris, Luhar Ismail, Panias Dimitris, Sakkas Konstantinos. Valorisation of glass waste for development of Geopolymer compositesMechanical properties and rheological characteristics: A review. Construction and Building Materials. 2019; 220

[32] Garcia-Lodeiro I., Palomo A., Fernández-Jiménez A., Macphee D.E.. Compatibility studies between N-A-S $-\mathrm{H}$ and C-A-S-H gels. Study in the ternary diagram $\mathrm{Na} 2 \mathrm{O}-\mathrm{CaO}-\mathrm{A} 12 \mathrm{O} 3-\mathrm{SiO} 2-\mathrm{H} 2 \mathrm{O}$. Cement and Concrete Research. 2011; 41(9)

[33] Yip Christina K., Lukey Grant C., Provis John L., van Deventer Jannie S.J.. Effect of calcium silicate sources on geopolymerisation. Cement and Concrete Research. 2008; 38(4)

[34] Granizo Maria Luz, Alonso Santiago, Blanco-Varela Maria T., Palomo Angel. Alkaline Activation of Metakaolin: Effect of Calcium Hydroxide in the Products of Reaction. Journal of the American Ceramic Society. 2004; 85(1)

This article is licensed under a Creative Commons Attriution 4.0 International License. 